\title{
組織不均質を考慮した三次元延性損傷シミュレーション法 一複相組織材料の延性予測一
}

\author{
大畑 充 ${ }^{1) *} \cdot$ 庄司 博人 ${ }^{1)} \cdot$ 南 二三吉 ${ }^{1)}$ \\ 3D-simulation of Ductile Damage Evolution in Multi-phase Steel with Heterogeneous Microstructures \\ Mitsuru OHATA, Hiroto SHoJ and Fumiyoshi Minami
}

Synopsis : The effort of this study is to establish simulation method for predicting the effect of mechanical and morphological characteristics of each constituent phase of two-phase steel on two types of ductile properties that has been found to be ductile crack growth resistance controlling mechanical properties; one is critical local strain that controls shear mode ductile cracking, and the other is stress triaxiality dependent ductility. Notched micro-tensile tests for ferrite-pearlite two-phase steel exhibits that ductile failures from specimen center with dimple mode and notch-root surface with shear mode are both controlled by micro-void nucleation at softer ferrite phase near ferrite/pearlite boundary. 3D micro-structural FE-model is developed for analyzing the stress/strain localization behaviors associated with heterogeneous microstructure in strength, and ductile damage model for reproducing damage evolution up to micro-void/micro-crack formation is proposed. The 3D mesoscopic damage simulation method is applied for simulating ductile cracking behaviors of notched tensile specimens of two-phase steel. The damage evolution associated with micro-structural heterogeneity up to ductile cracking from specimen center as well as notch-root surface is well predicted.

Key words: ductile damage model; micro-structural heterogeneity; ductile crack; stress triaxiality; 3D simulation.

\section{1. 緒言}

近年の高勒性材料の開発により，延性き裂の進展を伴う 場合の構造性能評価の重要性が益々増してきている。その ため, 延性き裂の進展抵抗を定量的に予測する技術の確立 が期待される。これまで, 構造部材の延性き裂進展抵抗を 予測する手法について精力的に検討されており，材料の損 傷挙動をモデル化（数式化）して数值シミュレーションに より直接予測する方法が各種提案されている ${ }^{1-6)}$ 。しかし， これらの損傷モデルに含まれる多くの材料特性パラメータ を直接的に同定することが困難なこと等から，いずれも， 実材料の微視的特性と延性き裂進展抵抗を定量的に対応づ けるものではない。これに対して, 著者らは, 鋼構造部材 の延性き裂発生・進展抵抗が材料の二種類の「延性特性」 に支配されることを見いだし7，これらの「延性特性」と関 係づけた数理損傷モデルを提案することで, 材料の機械的 特性と構造部材の延性き裂発生 - 進展抵抗を定量的に関連 づけるシミュレーション手法を構築してきた 8,9$) 。 二$ 二種類 の「延性特性」とは, 切欠き材の曲げ試験から得られる「切 欠き延性 (切欠き底からの延性き裂発生限界ひずみ)」と, 円周切欠き付丸棒引張試験から得られる「延性の応力多軸 度依存性 (限界相当塑性ひずみの応力多軸度依存性)」で,
それぞれ微視的プロセス・モードが異なるき裂の発生抵 抗 (せん断すべり型) と進展抵抗 (等軸ディンプル形成型) を支配するものである。Fig.1 は, 著者らの実験で得られた 種々の構造用鋼の「切欠き延性」と「延性の応力多軸度依 存性」をまとめて整理したものである7-12)。材料によって 多様な特性を示しており, 特に, 両特性が比較的独立した 特性を示すという特徵を有する。このように, 構造部材の

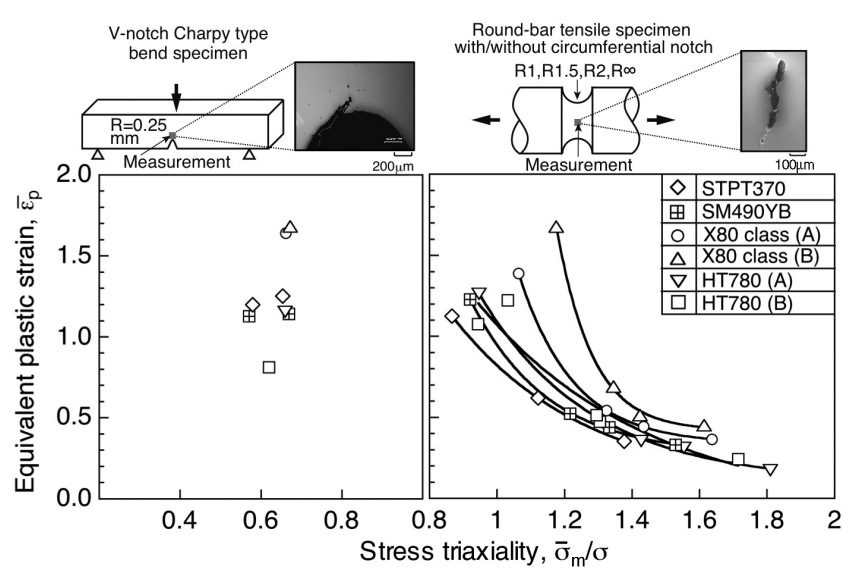

Fig. 1. Two kinds of ductility of various kinds of structural steels which controls ductile crack growth resistance of structural component with crack.

平成 25 年3月6日受付 平成 25年 5月20日受理 (Received on Mar. 6, 2013 ; Accepted on May 20,2013)

1) 大阪大学大学院 (Graduate School of Engineering, Osaka University, 2-1 Yamada-oka Suita Osaka 565-0871)

* Corresponding author : E-mail : ohata@mapse.eng.osaka-u.ac.jp

DOI : http://dx.doi.org/10.2355/tetsutohagane. 99.573 


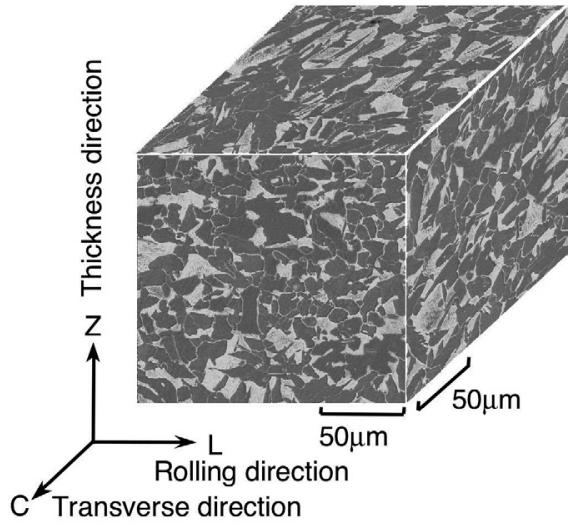

Fig. 2. Microstructure of SM490YB steel used.

(a) Type A
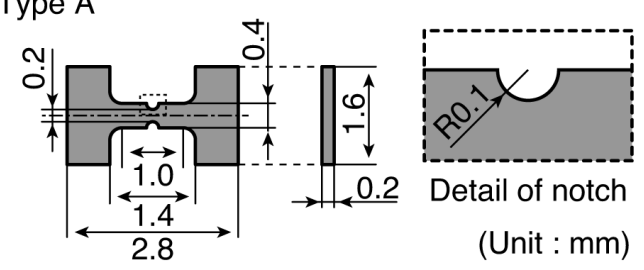

(b) Type B
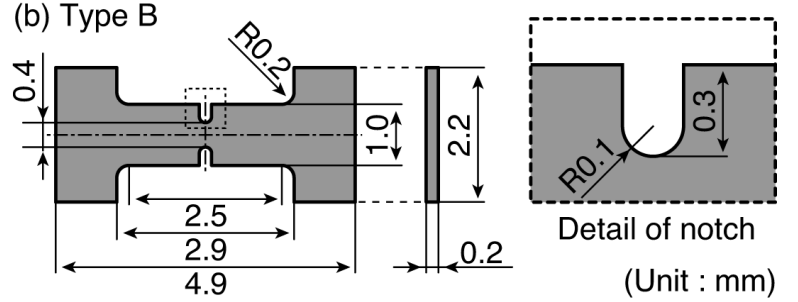

Fig. 3. Configuration of notched micro-tensile specimens used.

断面観察を行った。最大荷重点を大きく超えた負荷ひずみ レベルであるLevel 1で除荷した試験片においても，大き なボイドを確認することはできず，フェライト相とパーラ イト相の境界近傍の軟質相であるフェライト相側に, 1 2 $\mu \mathrm{m}$ 程度のマイクロボイドがわずかに見られるのみであっ た (Fig.6 (a))。さらにひずみを付与した Level 2で除荷し た試験片では, Fig.6 (b) に示すように, マイクロボイドが 大きく成長した様子は観察されず，マイクロボイドが増加 あるいは互いに連結しながら, また, マイクロボイド間で の損傷進展により, 主として相境界近傍のフェライト相内 にて微小なき裂を形成していることが確認できる。最終的 には, 応力ーひずみ曲線の屈曲点を超える負荷ひずみレべ ル (Level 3) では, Fig.6 (c) に示すように形成されたき裂 が大きく開口している様子が観察された。

このように, 試験片内部での損傷挙動は, 不均質組織の 影響を大きく受けており, 組織不均質による局所的な応力 /ひずみの局在化挙動に依存した結果であることが示唆さ れた。また, 一次ボイドと呼ばれる大きな介在物起点のボ イドの発生・成長が破断を支配するものではなく, 負荷の 後期になって生じるマイクロボイドの形成までの微視的な

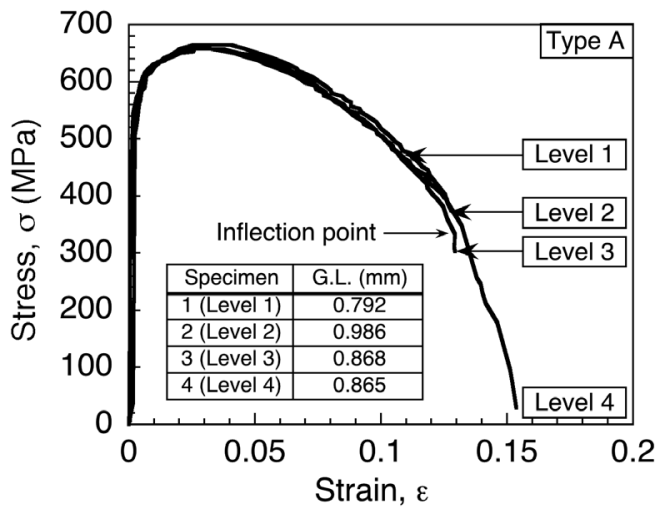

Fig. 4. Stress-strain curves for Type A specimen obtained by experiments.
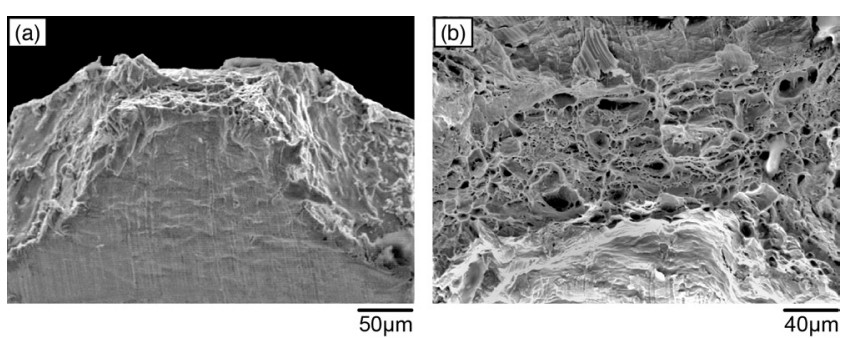

Fig. 5. Fracture appearance of Type A specimen.

(a) Whole view. (b) Magnified fracture surface.
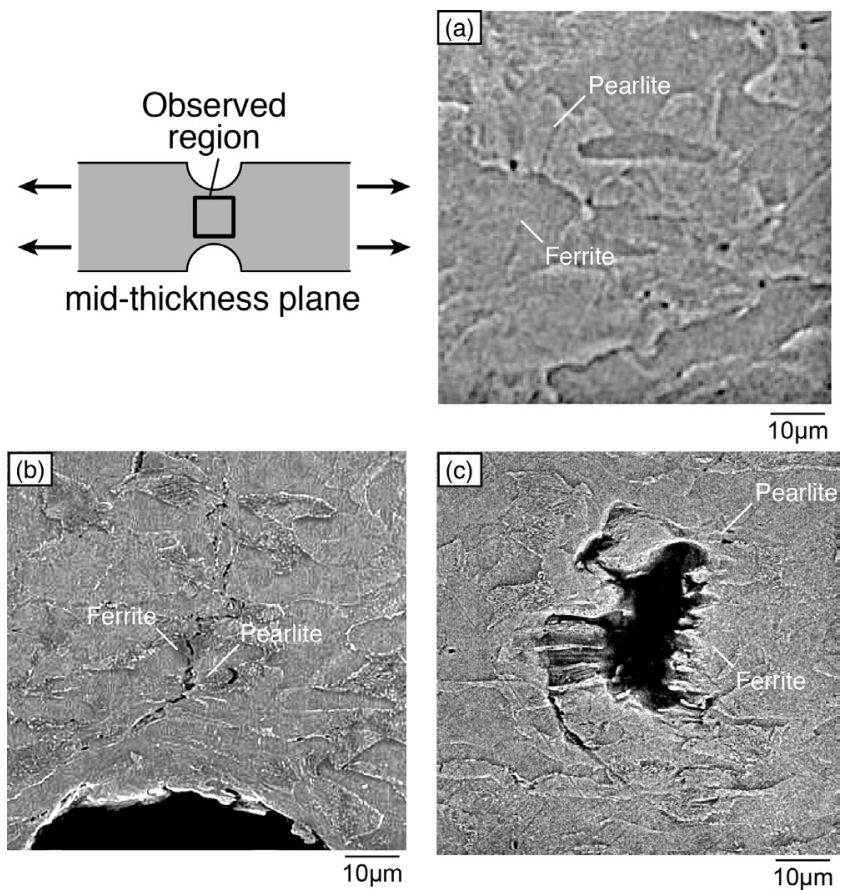

Fig. 6. Ductile damage evolution from specimen center for Type A specimen.

(a) Level 1. (b) Level 2. (c) Level 3.

損傷進展に支配されるき裂形成挙動を呈することがわかっ た。これは, 同材料を用いて行った丸棒引張試験によって 確認された挙動とほぼ同じであった ${ }^{11,18)}$ 。 


\section{$2 \cdot 3$ 部材表面の延性損傷挙動}

Type B 試験片の引張試験で得られた応力ーひずみ曲線 をFig.7に示す。応力とひずみの定義はFig.4 と同じである (ただし，初期標点間距離は $2 \mathrm{~mm}$ )。破断後の破面を観察し たところ, Fig.8に示すように切欠き底近傍ではせん断す心゙ り型の破面を呈しており，切欠き底から少し内部では等軸 ディンプルが観察された。これより，切欠き底表面から先 行して延性き裂が発生したものと推察される。

このような延性き裂発生に至るまでの内部の損傷進展 の様子を観察した。Fig.9（a）に示すように，負荷後期の Level 1 で切欠き底から延性き裂が発生し始めているが，マ イクロボイドの形成はほとんど観察されなかった。 Level 2 (Fig.9 (b)) では, 既に切欠き底から発生した延性き裂が約 $30 \mu \mathrm{m}$ 進展していることが確認され, 同時に, 試験片中央部 でも延性き裂の形成が確認された。このことから，延性き 裂が切欠き底表面から独立して発生したことが同われる が，そのき裂は主としてフェライト相側で進展しているこ とが観察された。

このように, 部材表面から生じるせん断型の延性き裂 も, 部材内部からの延性き裂と同様に, マイクロボイド発 生までの微視的な材料損傷に支配され，それは組織不均質 の影響を大きく受けることがわかった。

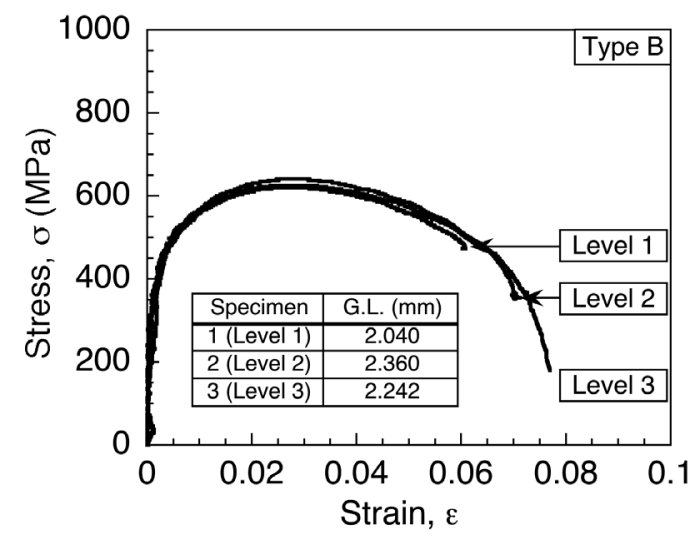

Fig. 7. Stress-strain curves for Type B specimen obtained by experiments.
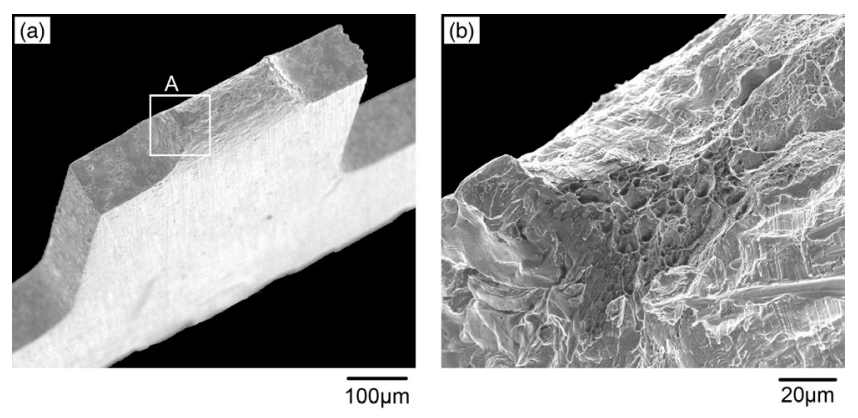

Fig. 8. Fracture appearance of Type B specimen. (a) Whole view. (b) Magnified fracture surface.

\section{3. 複相組織材料の延性損傷シミュレーション 法 16,17$)$}

\section{$3 \cdot 1$ アプローチ}

提案したシミュレーション法による二相組織材料の延性 破壊限界の予測のためのアプローチを Fig.10に示す。これ は, 二相組織を構成する各相の単相多結晶材料としての機 械的特性の情報と, 二相組織形態 (Morphology) の情報か ら，二相材料の延性破壊限界を予測することをねらったア プローチであり, 後述する「三次元不均質組織形態モデル」 と「延性数理損傷モデル」を組み合わせたシミュレーショ ン法である。必要な各相の機械的特性は, 丸棒引張試験な どで得られる「応力ーひずみ曲線」と，切欠き先端半径を 変化させた円周切欠き付丸棒引張試験から得られる「延性 の応力多軸度依存性」である。本手法を適用して, 組織不 均質による応力／ひずみの局在化挙動とそれに伴う損傷発 展をシミュレートすることで, モードが異なる挙動を呈す る部材内部打よび表面からの延性き裂発生挙動を区別なく 統一的に予測できる可能性が期待される。

\section{$3 \cdot 2$ 三次元不均質組織形態モデル化法}

不均質組織形態の影響を考慮した複相組織鋼の応力 /ひ ずみの局在化挙動を再現するには, 相間の強度的不均質に 起因する塑性拘束の影響を考慮する必要性から, 三次元モ デルを用いることが望ましい。そこで, 対象とする複相材 料の組織形態の統計的性質を再現可能な三次元不均質組織 モデル化手法を構築した。Fig.11にその手順の概略を示す。 まず，(a) ある領域内に存在する全結晶粒数に相当する母 点をランダムに三次元空間に分布させる。次に (b) Voronoi tessellation法によって三次元結晶粒モデルを作成し，(c) 第二相分率から決まる結晶粒数に応じて第二相をランダム に選択する。最後に (d) 自動メッシングにより有限要素分 割を行う。本手法により, 実材料の組織形態を模擬する解 析モデルを作成することができるが, 現在では, 母点の分
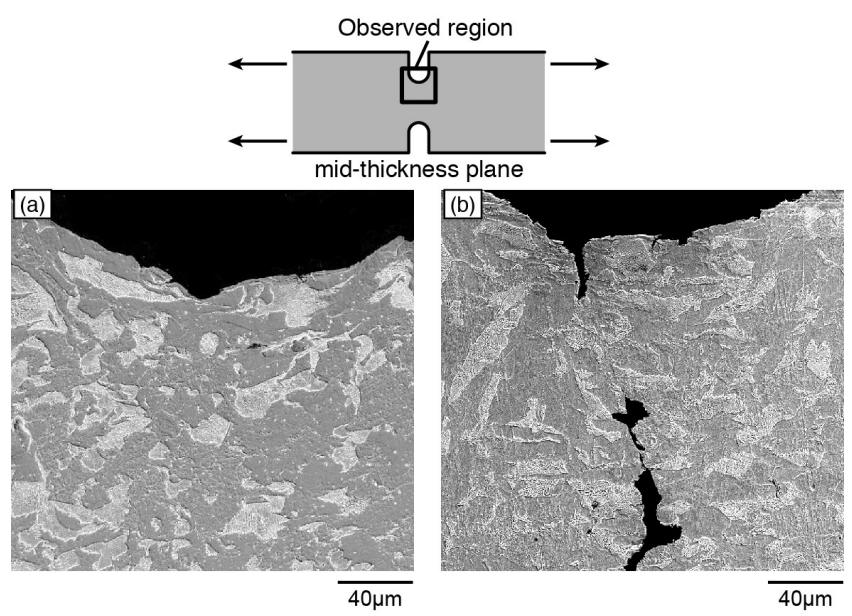

Fig. 9. Ductile damage evolution from notch-root surface of Type B specimen. (a) Level 1. (b) Level 2. 


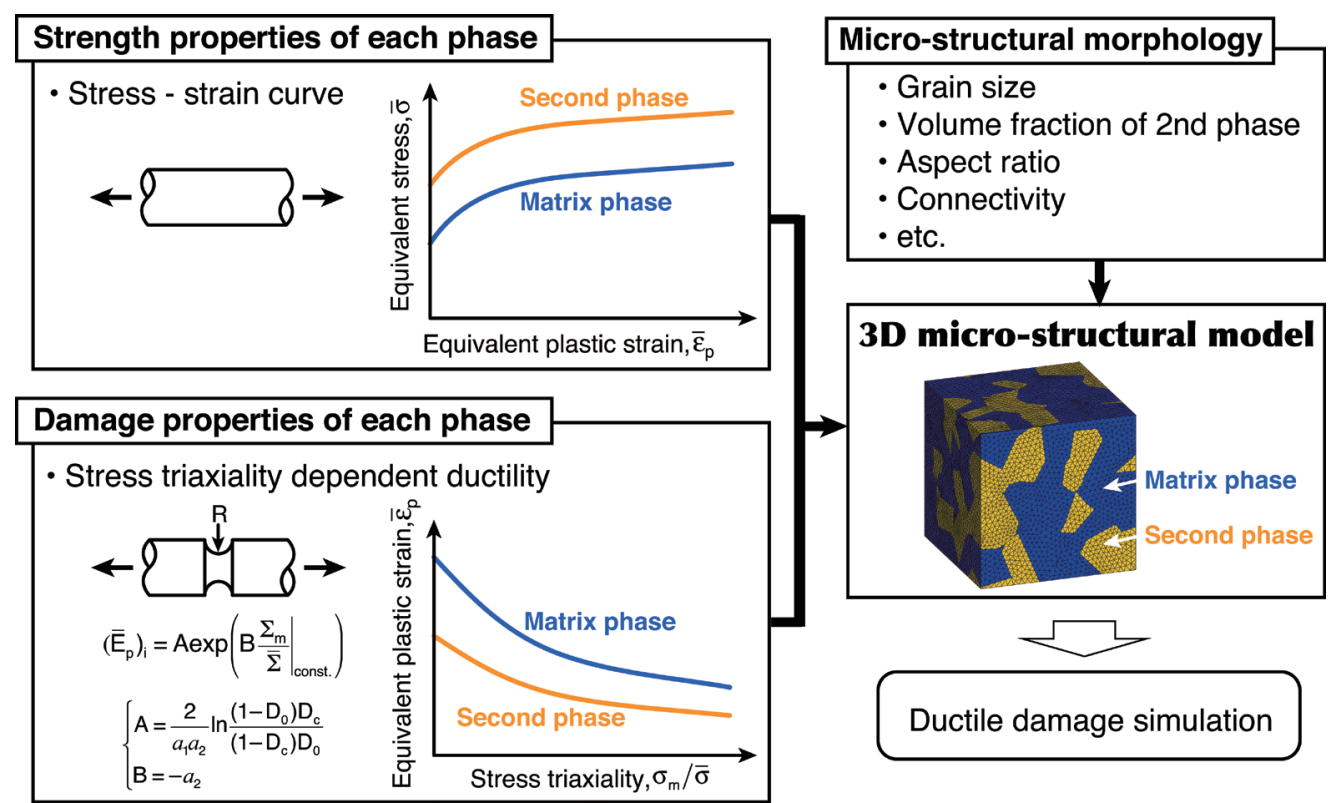

Fig. 10. Approach for predicting ductile fracture behavior/limit of two-phase steel. (Online version in color.)

布方法や第二相の選択方法を工夫することで, より実組織 形態に近いモデルの作製を可能としている。

\section{$3 \cdot 3$ 延性損傷数理モデル}

材料中で巨視的なボイドや微視き裂が形成されるまでの 多軸応力下における塑性ひずみの増加による材料損傷進展 と，それに伴う剛性の低下を再現する延性数理損傷モデル を構築した。材料の損傷は, タングル化した転位などの格 子欠陥の増大/成長や微小な介在物を起点としたナノ・サ ブミクロンサイズのボイドの発生・成長と捉え, この微視 的損傷が蓄積することでマイクロボイド/マイクロクラッ クが形成されると考えるものである。そこで, 微視的損傷 増加を体積ひずみ増分の塑性成分とする損傷度 $D$ を想定し た。

$$
d D=(1-D) d E_{\mathrm{m}}^{\mathrm{p}}
$$

ここで, $d E_{\mathrm{m}}^{\mathrm{p}}$ はユニットセルの体積ひずみ増分の塑性成分 である。この損傷度 $D$ の増加とそれによる剛性の低下を連 成させるため, 式 (2) に示す Gurson-Tvergaard ${ }^{1,2)}$ の多孔質 体の損傷モデルをべースとした新しい降伏関数を提案し た。

$$
\Phi=\left(\frac{\bar{\Sigma}}{\bar{\sigma}}\right)^{2}+a_{1} D^{*} \exp \left(a_{2} \frac{\Sigma_{\mathrm{m}}}{\bar{\sigma}}\right)-1=0
$$

ここで, $D^{*}$ は有効損傷度， $\bar{\Sigma}$ は損傷を含むユニットセル の, また $\bar{\sigma}$ は材料マトリックスの相当応力 (相当塑性ひず みの関数)， $\Sigma_{\mathrm{m}}$ はユニットセルの平均垂直応力である。流 動応力が応力多軸度 $\Sigma_{\mathrm{m}} / \bar{\sigma}$ の影響を受けることを加味し ており, 塑性ひずみ増加に伴う損傷進展が高応力多軸度に よって促進されることが反映される。 $a_{1}, a_{2}$ は材料定数 (損 傷パラメータ) であり, 提案した降伏関数から導かれる式
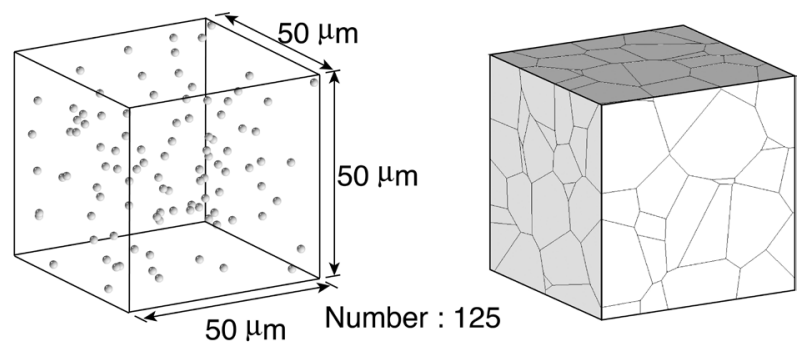

(a) Crystalline nucleus

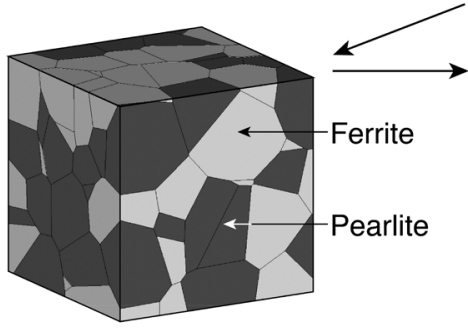

(b) Voronoi polyhedra

(c) 3D two-phase polycrystalline model

(d) 3D two-phase polycrystalline FE-model

Fig. 11. Method for creating 3D two-phase polycrystalline FEmodel.

(3) との対応から, 当該材料 (構成組織) の限界相当塑性ひ ずみと応力多軸度との関係式である損傷限界曲線から一義 的に決定できる。

$$
\left(\bar{E}_{\mathrm{p}}\right)_{\mathrm{i}}=A \exp \left(\left.B \frac{\Sigma_{\mathrm{m}}}{\bar{\Sigma}}\right|_{\text {const. }}\right), \quad \text { where }\left\{\begin{array}{l}
A=\frac{2}{a_{1} a_{2}} \ln \frac{\left(1-D_{0}\right) D_{\mathrm{c}}}{\left(1-D_{\mathrm{c}}\right) D_{0}} \ldots . . \\
B=-a_{2}
\end{array}\right.
$$

ここで, $\left(\bar{E}_{\mathrm{p}}\right)_{\mathrm{i}}$ はマイクロボイド/マイクロクラックが形 成し始める塑性ひずみ (損傷限界塑性ひずみ) であり, $D_{0}$, $D_{\mathrm{c}}$ はそ妃ぞれ初期損傷度と加速限界損傷度である。すなわ ち, シミュレーションに必要な全ての材料パラメータが, Fig.10に示した平滑丸棒試験片と円周切欠き付丸棒試験片 
の引張試験の結果 (「応力ーひずみ曲線」と「延性の応力多 軸度依存性」) のみから決定できる。なお，有効損傷度 $D^{*}$ は式 (4) で表し， $D$ が $D_{\mathrm{c}}$ に達すると損傷が相互作用を引き

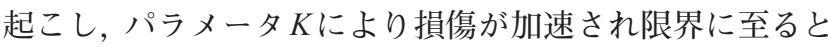
想定した。

$$
D^{*}=\left\{\begin{array}{ccc}
D & \text { for } & D \leq D_{\mathrm{c}} \\
D_{\mathrm{c}}+K\left(D-D_{\mathrm{c}}\right) & \text { for } & D>D_{\mathrm{c}}
\end{array} .\right.
$$

なお, 本手法では, 初期損傷度 $D_{0}$, 加速限界損傷度 $D_{\mathrm{c}}$ は工 ニットセルの剛性にほとんど影響を及ぼさないような小さ な值であれば良く，それぞれ0.0001，0.001とした。また， 損傷加速パラメータ $K$ は，想定した $D_{0}$ および $D_{\mathrm{c}}$ に応じて 丸棒引張試験片の実験とシミュレーションが一致するよ うに決定すべきものであるが，従来の知見 ${ }^{8,9)}$ に基づいて $K=4$ と設定した。すなわち, $D_{0}, D_{\mathrm{c}}$ および $K$ は材料に依 存しないパラメータであり, 材料依存の特性はパラメータ $a_{1}, a_{2}$ で代表される。

\section{4. 提案シミュレーション法による延性損傷挙動評 価}

前述したシミュレーションの手順に従い, まず供試鋼材 の組織形態を再現する三次元不均質組織形態モデルを作成 する。次に，供試鋼材を構成するフェライト相とパーライ 卜相の強度特性および損傷特性を決定する。これらを組み 合わせて延性損傷シミュレーションを行い, 部材内部およ び表面からの延性損傷挙動を評価する。

\section{$4 \cdot 1$ 三次元不均質組織形態モデルの作成}

対象とした二相組織鋼に対して, シミュレーションに用 いる解析モデルを, 三次元不均質モデル化法を用いて作製 する。組織観察の結果から得られた平均結晶粒径が約 25 $\mu \mathrm{m}$, パーライト分率が約 $30 \%$ であることを再現し, Fig. 12

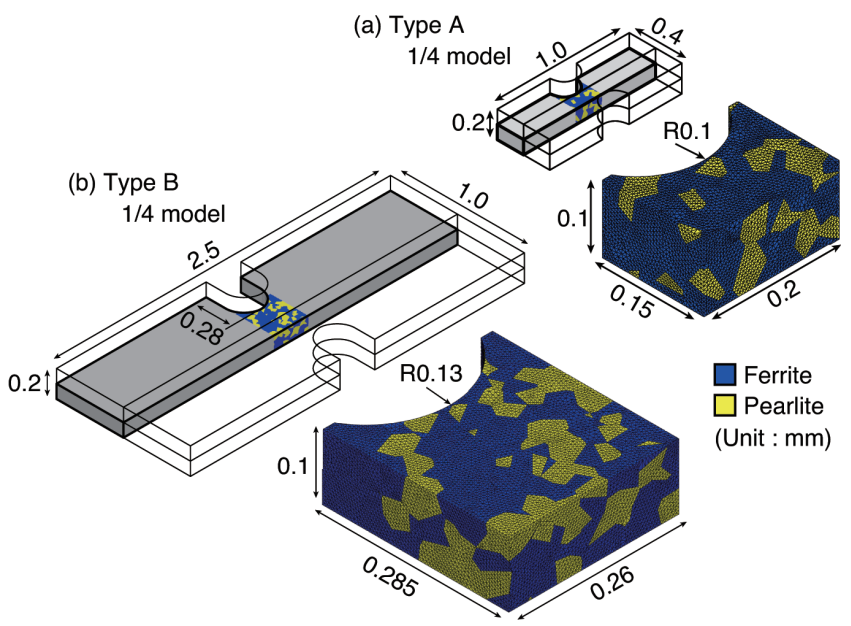

Fig. 12. Meso-scale 3D FE-models of notched micro-tensile specimens. (a) Type A specimen. (b) Type B specimen. (Online version in color.)
に示すように実験で用いた微小試験片そのものの解析モデ ルを作製した。不均質組織形態モデルは損傷が及ぶ切欠き 底断面近傍にのみ配置し，それ以外の領域は均質モデルと した。また,いずれの解析モデルも試験片平行部の 1/4 部 分をモデル化した。要素は 4 節点 4 面体要素を用い, 平均 要素寸法は約 $5 \mu \mathrm{m}$, Type A 試験片の解析モデルの節点数は 27826 で要素数は 144410 であり, Type B 試験片の節点数は 60143 で要素数は 324553 である。

\section{$4 \cdot 2$ 各相の材料特性の決定}

シミュレーションに必要な二相組織を構成するフェライ ト, パーライト各相の材料特性を決定するためには, 各相 と同じ特性を有する多結晶単相材料を作製することで，前 述の丸棒引張試験および円周切欠き付丸棒引張試験を実施 して決定することができる。しかし本研究では，二相材の 「応力ーひずみ曲線」と「延性の応力多軸度依存性」から, 各相の特性を仮定して決定することとした。

$4 \cdot 2 \cdot 1$ 各相の強度特性

二相材の平滑丸棒引張試験で得られた応力ーひずみ特 性から, 各相の応力ーひずみ特性を以下のように仮定して 決定した。式 (5) に示すように, 各相の降伏応力 $\sigma_{\mathrm{Y}}$ と引 張強さ $\sigma_{\mathrm{T}}$ の比が, 各相の平均ビッカース硬さ $H V$ の比と等 しく, また一様伸び $\varepsilon_{\mathrm{T}}$ の比は $H V$ の逆比と等しいと仮定し た。また二相材の特性が式（6）に示す混合則に従うものと 仮定し, 各相の降伏応力と引張強さ，一様伸びを決定した。

$$
\frac{H V^{\mathrm{F}}}{H V^{\mathrm{P}}}=\frac{\sigma_{\mathrm{Y}}{ }^{\mathrm{F}}}{\sigma_{\mathrm{Y}}{ }^{\mathrm{P}}}=\frac{\sigma_{\mathrm{T}}{ }^{\mathrm{F}}}{\sigma_{\mathrm{T}}{ }^{\mathrm{P}}}=\frac{\varepsilon_{\mathrm{T}}{ }^{\mathrm{P}}}{\varepsilon_{\mathrm{T}}{ }^{\mathrm{F}}}=\frac{276}{198}
$$

$$
\left\{\begin{array}{l}
\sigma_{\mathrm{Y}}=\left(1-V_{f}^{\mathrm{P}}\right) \sigma_{\mathrm{Y}}^{\mathrm{F}}+V_{f}^{\mathrm{P}} \sigma_{\mathrm{Y}}^{\mathrm{P}} \\
\sigma_{\mathrm{T}}=\left(1-V_{f}^{\mathrm{P}}\right) \sigma_{\mathrm{T}}^{\mathrm{F}}+V_{f}^{\mathrm{P}} \sigma_{\mathrm{T}}^{\mathrm{P}} \\
\varepsilon_{\mathrm{T}}=\left(1-V_{f}^{\mathrm{P}}\right) \varepsilon_{\mathrm{T}}^{\mathrm{F}}+V_{f}^{\mathrm{P}} \varepsilon_{\mathrm{T}}^{\mathrm{P}}
\end{array}\right.
$$

ここで, $V_{f}^{\mathrm{P}}$ はパーライト分率である。さらに, 各相が式 （7）に示すSwiftの加工硬化則に従うものと仮定し, $n$ と $\alpha$ を求めて応力ーひずみ特性を決定した。このように決定し た各相の応力ーひずみ曲線を Fig.13 (a)に示す。

$$
\bar{\sigma}=\sigma_{\mathrm{Y}}\left(1+\frac{\bar{\varepsilon}_{\mathrm{p}}}{\alpha}\right)^{n},\left\{\begin{array}{l}
\sigma_{\mathrm{T}}=\sigma_{\mathrm{Y}}\left(\frac{n}{\alpha}\right)^{n} \exp (\alpha-n) \\
\varepsilon_{\mathrm{T}}=\exp (n-\alpha)-1
\end{array}\right.
$$

\section{$4 \cdot 2 \cdot 2$ 各相の損傷特性}

二相材の「延性の応力多軸度依存性」から, 各相の損傷 特性（式 (2) の材料定数 $a_{1}, a_{2}$ ) を実験・観察結果に基づき ながら仮定して決定した。

対象二相材に対して切欠き先端半径を変化させた円周 切欠き付丸棒引張試験を行うことで「延性の応力多軸度 依存性」を求め, 損傷パラメータ決定のための損傷限界曲 線（(式 (3) : 延性損傷限界ひずみと応力多軸度の関係) を Fig.13（b）のように決定した。用いた試験片や決定手法の 

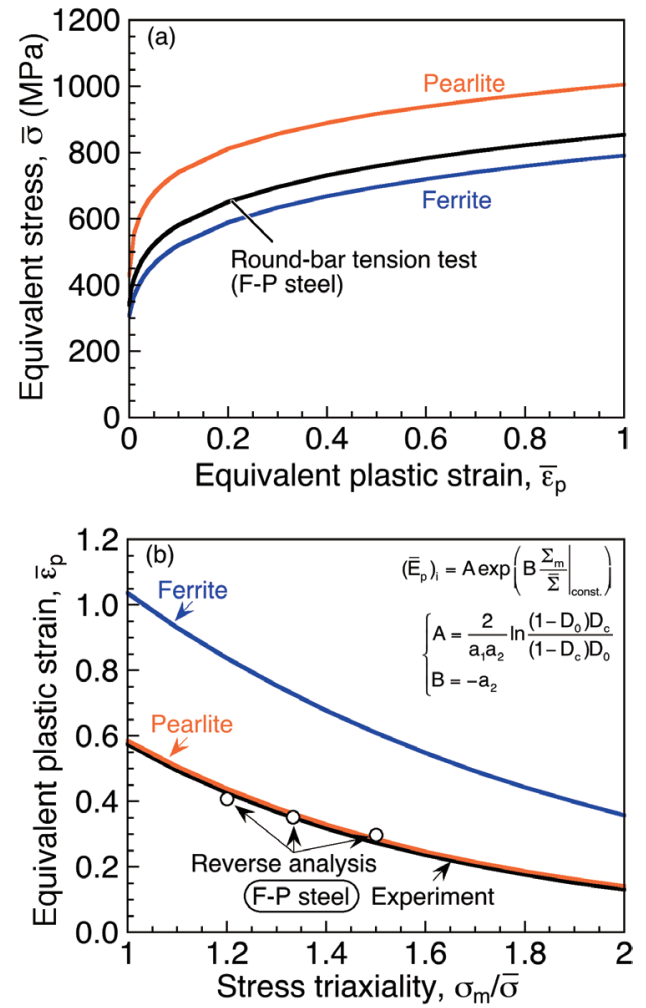

Fig. 13. Mechanical properties of constituent phases (Ferrite and Pearlite phases) of two-phase steel needed for damage simulation. (a) Equivalent stress-equivalent plastic strain curves. (b) Stress triaxiality dependent ductility. (Online version in color.)

詳細は文献9,11)を参照いただきたい。これに対して，硬質 のパーライト相はほとんど損傷を受けていないという観察 結果から, 本研究では便宜的にパーライト相の損傷限界曲 線を二相材のそれと等しいものと仮定した。また, 軟質の フェライト相の損傷限界ひずみは, 組織不均質に起因する 応力／ひずみ集中により損傷が進行しやすいために二相 材の限界ひずみよりも高い特性を有することに鑑み, 不均 質組織でモデル化した立方体代表体積要素を用いたシミュ レーションによる損傷限界ひずみが二相材の特性（Fig.13 (b) の特性) と合致するように逆解析により決定した ${ }^{19)}$ 。 以上のようにして決定したフェライト相およびパーライト 相の損傷限界曲線を，二相材の限界曲線と合わせて Fig.13 （b）に示す。また，これらから決定した損傷パラメータを Table 3 に整理した。

\section{$4 \cdot 3$ 延性損傷シミュレーション}

提案手法を用いて実験で得られた延性損傷挙動の再現性 を検討するために, Fig.12に示した解析モデルを用いて損 傷シミュレーションを行った。解析にはABAQUS Standard Ver.6.7を用い, User Subroutine UMATにより $3 \cdot 3$ 節で提案 した「延性損傷数理モデル」を導入して解析を行った。材 料モデルには提案した降伏関数 $\Phi$ 塑性ポテンシャルとす る関連流れ則に基づいた塑性モデルを用い，また，増分型 構成則の記述にはCauchy応力の Jaumann 速度を用いてい
Table 3. Damage parameters identified for Ferrite and Pearlite phases.

\begin{tabular}{c|cc|ccc}
\hline & $\mathrm{a}_{1}$ & $\mathrm{a}_{2}$ & $\mathrm{D}_{0}$ & $\mathrm{D}_{\mathrm{c}}$ & $\mathrm{K}$ \\
\hline Ferrite & 1.45 & 1.06 & \multirow{2}{*}{0.0001} & 0.001 & 4 \\
\cline { 1 - 3 } Pearlite & 1.28 & 1.47 & & & \\
\hline
\end{tabular}

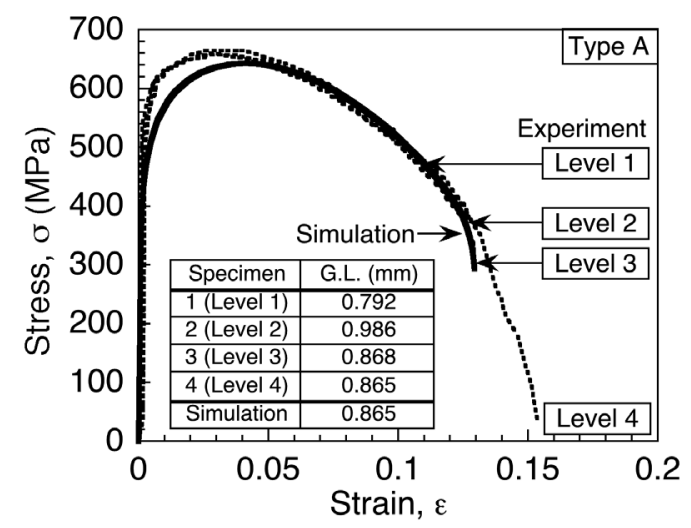

Fig. 14. Stress-strain curves obtained by experiment and simulation for Type A specimen.

る。なお，均質モデル部には通常の Mises 降伏条件に従う 塑性構成式を採用し, 対象二相材の丸棒引張試験で得られ る応力ーひずみ関係を用いた。

まず確認のために, 試験片内部からの延性き裂発生が確 認されたType A 試験片の延性損傷挙動・限界の再現性に ついて検討した。シミュレーションで得られた応力ーひず み曲線を Fig.4に示した実験結果と比較して Fig.14に示す。 また, 負荷に伴う損傷進展の様子を実験・観察結果と比較 してFig.15に示した。Level 1ではわずかにマイクロボイド (シミュレーションでは剛性が消失した要素) が発生し始 めており, Level 2ではマイクロボイドが増加, 連結して微 小なき裂を形成し, Level 3 にてき裂が大きく開口している 様子がシミュレーションでも再現することができた。この ような損傷が，主にフェライトノパーライト相境界のフェ ライト相で進展していることも, 実験・観察で得られた結 果と合致する。また，破断直前の急激な荷重低下が生じる ひずみレベルも良く一致することが確認できた。

そこで, 切欠き底からせん断すべり型の延性き裂の発生 が確認されたType B 試験片の延性損傷挙動・限界につい ての検討を行った。ここでは, 巨視的な応力/ひずみ場と の比較考察のために, 損傷を考虑しないMises 降伏条件に 従う材料構成式を用いた均質連続体モデルに対する解析 も行った。Fig.16に, 損傷シミュレーションで得られた応 カーひずみ曲線を, 実験で得られた結果 (Fig.7) と比較し て示す。Fig.16中に示すLevel 0の段階において, 切欠き底 断面近傍の各相内の相当塑性ひずみと応力多軸度, および それに起因した損傷状態を損傷率 $D^{*} / D^{*}$ cr (剛性を失う損 傷度 $D^{*}{ }_{\mathrm{cr}}\left(=1 / a_{1}\right)$ に対する損傷度 $D^{*}$ の割合) として Fig.17 に示した。図中の白線で囲まれた部分はパーライト相であ 


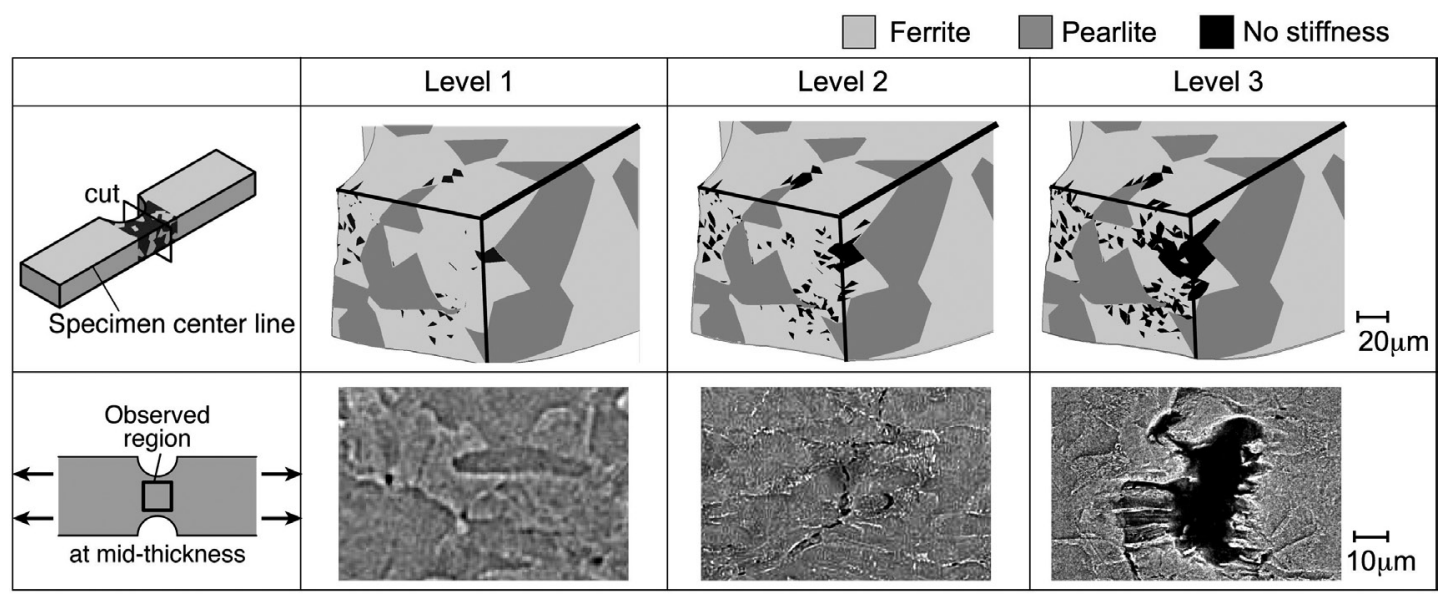

Fig. 15. Comparison between simulated and observed ductile damage evolution for Type A specimen.

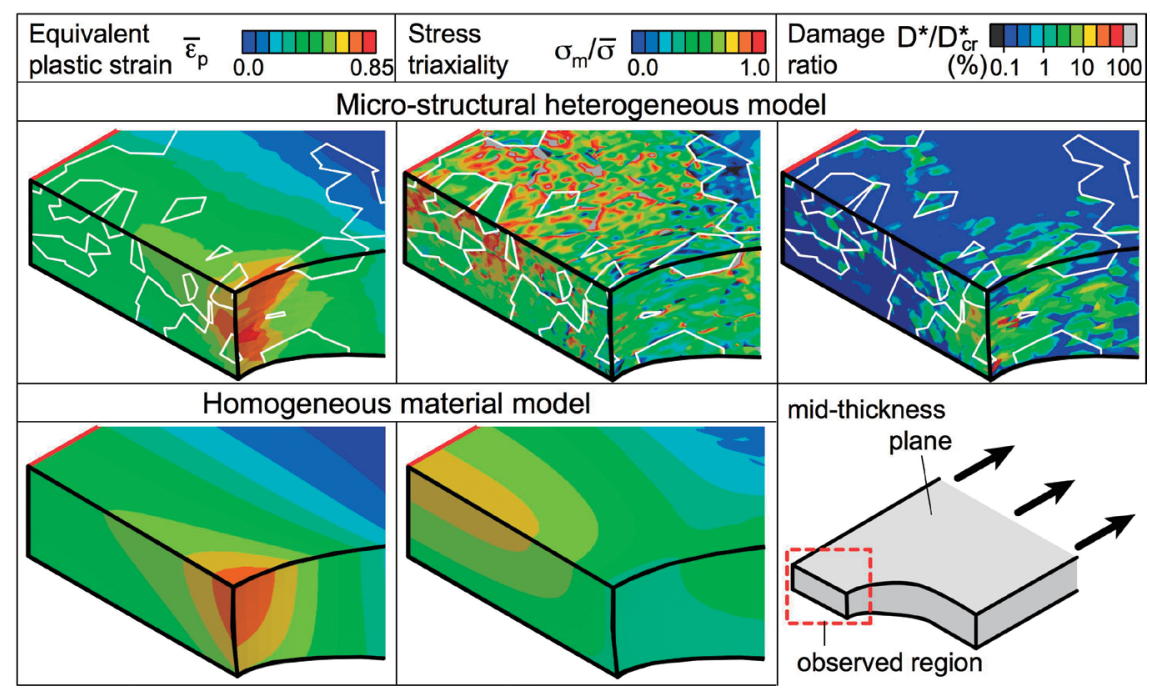

Fig. 17. Distributions of equivalent plastic strain, stress triaxiality and damage ratio obtained by simulation for Type B specimen (at Level 1 in Fig.16).

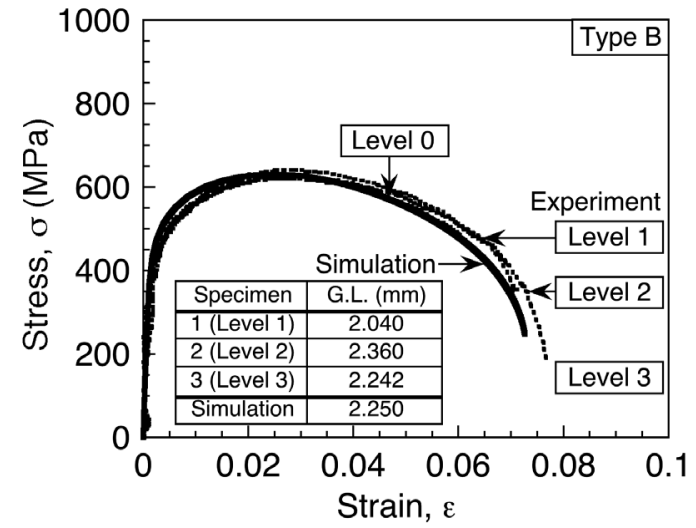

Fig. 16. Stress-strain curves obtained by experiment and simulation for Type B specimen.

る。均質連続体モデルでは，切欠き底表面近傍で塑性ひず みや応力多軸度はほほ一様な分布を示しており, 特に損傷 進展速度に影響を及ぼす応力多軸度は試験片中央部に比べ
てかなり小さい。一方, 不均質モデルでは, 切欠き底近傍 で高い塑性ひずみが形成されているが，その中でも，フェ ライトーパーライト相境界近傍のフェライト相側に高い塑 性ひずみが局在化していることがわかる。また，切欠き底 表面近傍にも関わらず組織不均質の影響を受けて相境界近 傍のフェライト相では応力多軸度が高められた領域が見 られる。このような挙動に起因して, 切欠き底表面にて先 行して損傷が生じる挙動が再現でき得ることがわかった。 Fig.18には, 実験で延性き裂が確認されたLevel 1 および Level 2 の付与ひずみレベルにおける損傷状態（既に剛性を 失ってマイクロボイドあるいは微視き裂となった領域)を， 実煥観察結果と比較して示した。本シミュレーションによ り, 実験とほぼ同じ付与ひずみレベルにおいて, 切欠き底 表面からのき裂が主として二相境界のフェライト相側で進 行する挙動が再現できた。

以上のことより, 本シミュレーション手法によって, フェライトーパーライト二相組織を構成する各相の機械的 


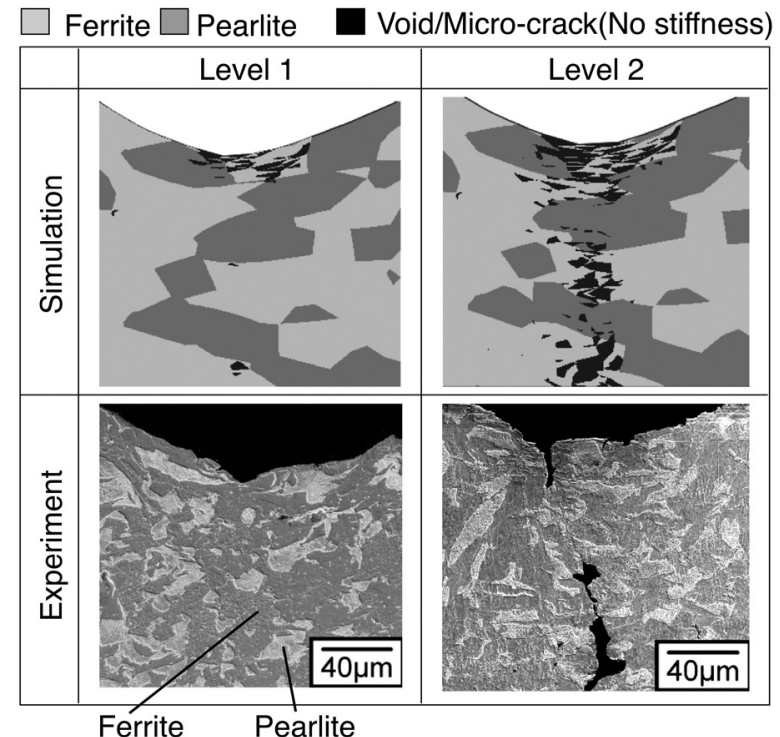

Fig. 18. Comparison between simulated and observed ductile damage evolution for Type B specimen.

特性と不均質組織形態の情報から, 部材内部・表面の巨視 的な応力/ひずみ状態に起因したモードが異なる延性き裂 の形成挙動を統一的に評価可能であることが実証された。 これにより, 構造部材の延性き裂発生・進展抵抗を支配す る二相組織鋼の二種類の巨視的「延性特性」である「切久 き延性」打よび「延性の応力多軸度依存性」と, 各相の材料 特性との関係を予測できる可能性が示された。

\section{5. 結言}

本研究では，フェライトーパーライト二相組織を有する 構造用鋼を対象として, 著者らが提案した組織不均質を考 慮した延性損傷シミュレーション手法を適用することで, 部材内部・表面の巨視的な応力 /ひずみ状態に起因した モードが異なる延性き裂の形成挙動を統一的に評価し得る かどうかの検討を行った。本手法は，二相組織を構成する 各相の単相多結晶材料としての機械的特性と二相組織形態 の情報から，二相材料の延性破壞限界を予測することをね らったアプローチであり, 応力/ひずみの局在化挙動を再 現するための三次元不均質組織形態モデルと延性数理損 傷モデルを組み合わせたシミュレーション法である。本シ
ミュレーションにより, 浅い切欠き材の引張試験で見られ た試験片内部からの等軸ディンプルを伴う延性き裂発生だ けでなく, 深い切欠き材の引張試験で得られた切欠き底表 面からのせん断すべり型の延性き裂発生の両挙動を再現す ることができた。すなわち, 各相の強度特性と応力多軸度 依存型の損傷限界特性のみで, 組織不均質に起因した応力 /ひずみの局在化挙動を再現する解析モデルを用いること で, 部材内部・表面によらず延性き裂の発生挙動・限界を 統一的に評価できることが実証された。

\section{謝辞}

本研究の実施にあたり, 大阪大学大学院 (当時) の鈴木 翠君に一部の実験・観察で協力を得た。また, 本研究の一 部は，(社）日本鉄鋼協会第 18 回鉄鋼研究振興助成 (代表 : 大畑充）を受けて実施したものであり，ここに謝意を表す る。

\section{文献}

1 ) A.L.Gurson: J. Eng. Mat. Tech., 99(1977), 2.

2 ) V.Tvergaard and A.Needleman: Acta Metall., 32(1984), 157.

3 ) G.Roussrlier: Nucl. Eng. Des., 105(1987), 97.

4 ) J.B.Leblond, G.Perrin and P.Suquet: Int. J. Plast., 10(1994), 213.

5 ) J.Lemaitre: J. Eng. Mat. Tech., 107(1985), 83.

6 ) J.L.Chaboche: Trans. ASME. J. Appl. Mech, 55(1988), 59.

7 ) M.Ohata, T.Fukahori and F.Minami: Tetsu-to-Hagané, 94(2008), 57.

8 ) T.Fukahori, M.Ohata, F.Minami, Y.Kayamori and T.Inoue: Tetsu-toHagané, 94(2008), 222.

9 ) M.Ohata, T.Fukahori and F.Minami: Int. J. Damage Mech., 19(2010), 441.

10) M.Ohata and M.Toyoda: Proc. of the 22nd Int. Conf. Offshore Mech. Arctic Eng., ASME, (2003), OMAE2003-37184.

11) M.Ohata and M.Toyoda: Sci. Tech. Adv. Mater., 5(2004), 241.

12) T.Kawabata, K.Arimochi, M.Ohata, M.Mochizuki and M.Toyoda: $Q$. J. Jpn. Weld. Soc., 22(2004), No.4, 515.

13) K.Ueda, S.Endo and T.Ito: JFE Tech. Rep., 18(2007), 23.

14) N.Konda, K.Arimochi, K.Fujiwara, A.Nagayoshi, A.Inami, M.Yamashita and H.Yajima: J. Soc. Nav. Archit. Jpn., 190(2001), 5.

15) K.Nakajima, H.Shimanuki, T.Nose and T.Ishikawa: Q. J. Jpn. Weld. Soc., 27(2009), 13.

16) M.Ohata, A.Ui and F.Minami: Mat. Sci. Forum, 539(2007), 2168.

17) M.Ohata, M.Suzuki, A.Ui and F.Minami: Eng. Fract. Mech., 77(2010), 277.

18) M.Ohata and M.Toyoda: Mat. Sci. Forum, 512(2007), 31.

19) H.Shoji, M.Ohata and F.Minami: Tetsu-to-Hagané, submitted. 